\title{
Niclosamide Exhibits Potent Anticancer Activity and Synergizes with Sorafenib in Human Renal Cell Cancer Cells
}

\author{
Xinyi Yua,b Feng Liu ${ }^{\mathrm{b}, \mathrm{c}}$ Liyi Zeng ${ }^{\mathrm{b}, \mathrm{d}}$ Fang He $\mathrm{e}^{\mathrm{a}, \mathrm{b}}$ Ruyi Zhang ${ }^{\mathrm{b}, \mathrm{e}}$ Shujuan Yan ${ }^{\mathrm{b}, \mathrm{e}}$ \\ Zongyue Zeng ${ }^{b, e} \quad$ Yi Shu ${ }^{b, c, e} \quad$ Chen Zhao ${ }^{a, b} \quad$ Xingye Wu ${ }^{a, b} \quad$ Jiayan Lei ${ }^{a, b}$ \\ Wenwen Zhang ${ }^{b, f} \quad$ Chao Yang ${ }^{b, c} \quad K e$ Wu ${ }^{b, c} \quad$ Ying Wu ${ }^{b, g}$ Liping An ${ }^{b, h}$ \\ Shifeng Huang ${ }^{a, b}$ Xiaojuan Ji ${ }^{b, c} \quad$ Cheng Gong ${ }^{b, i}$ Chengfu Yuan ${ }^{b, j}$ \\ Linghuan Zhang ${ }^{b, c}$ Yixiao Fenga, ${ }^{a, b}$ Bo Huang ${ }^{b, d, k}$ Wei Liu ${ }^{a, b}$ Bo Zhang ${ }^{b, h}$ \\ Zhengyu Daib,l Xi Wang ${ }^{b, e}$ Bo Liua ${ }^{a, b}$ Rex C. Haydon ${ }^{b}$ Hue H. Luu $^{b}$ \\ Hua Gan ${ }^{a}$ Tong-Chuan He $\mathrm{H}^{\mathrm{b}}$ Liqun Chen ${ }^{\mathrm{a}, \mathrm{b}}$
}

aDepartments of Nephrology, Orthopaedic Surgery, Cardiology, General Surgery, Plastic Surgery and Clinical Laboratory Medicine, the First Affiliated Hospital of Chongqing Medical University, Chongqing, China, ${ }^{b}$ Molecular Oncology Laboratory, Department of Orthopaedic Surgery and Rehabilitation Medicine, The University of Chicago Medical Center, Chicago, USA, 'Stem Cell Biology and Therapy Laboratory, Ministry of Education Key Laboratory of Child Development and Disorders, The Children's Hospital of Chongqing Medical University, Chongqing, dDepartment of Infection Control, Zhuzhou Central Hospital, and the Affiliated Zhuzhou Hospital of Xiangya Medical College of Central South University, Zhuzhou, eMinistry of Education Key Laboratory of Diagnostic Medicine and School of Laboratory Medicine, Chongqing Medical University, Chongqing, ${ }^{f}$ Department of Obstetrics and Gynecology, the Affiliated University-Town Hospital, Chongqing Medical University, Chongqing, 9Department of Immunology and Microbiology, Beijing University of Chinese Medicine, Beijing, "Key Laboratory of Orthopaedic Surgery of Gansu Province and the Department of Orthopaedic Surgery, the Second Hospital of Lanzhou University, Lanzhou, 'Department of Surgery, the Affiliated Zhongnan Hospital of Wuhan University, Wuhan, jDepartment of Biochemistry and Molecular Biology, China Three Gorges University School of Medicine, Yichang, kDepartment of Clinical Laboratory Medicine, the Second Affiliated Hospital of Nanchang University, Nanchang, 'Department of Orthopaedic Surgery, Chongqing Hospital of Traditional Chinese Medicine, Chongqing, China

\section{Key Words}

Niclosamide - Renal cell carcinoma - Kidney cancer - Drug repurposing - Metastatic renal cancer • Targeted therapy

\footnotetext{
Abstract

Background/Aims: As the most lethal urological cancers, renal cell carcinoma (RCC) comprises a heterogeneous group of cancer with diverse genetic and molecular alterations. There is an unmet clinical need to develop efficacious therapeutics for advanced, metastatic and/or relapsed RCC. Here, we investigate whether anthelmintic drug Niclosamide exhibits anticancer activity and synergizes with targeted therapy Sorafenib in suppressing RCC cell proliferation.

Tong-Chuan He, MD, PhD

and Liqun Chen, MD

Molecular Oncology Laboratory, The University of Chicago Medical Center, 5841 South

Maryland Avenue, MC 3079, Chicago, IL 60637 (USA)

E-Mail tche@uchicago.edu,609118212@qq.com
} 
Yu et al.: Repurposing Niclosamide as Anti-RCC Agent

Methods: Cell proliferation and migration were assessed by Crystal violet staining, WST-1 assay, cell wounding and cell cycle analysis. Gene expression was assessed by qPCR. In vivo anticancer activity was assessed in xenograft tumor model. Results: We find that Niclosamide effectively inhibits cell proliferation, cell migration and cell cycle progression, and induces apoptosis in human renal cancer cells. Mechanistically, Niclosamide inhibits the expression of C-MYC and E2F1 while inducing the expression of PTEN in RCC cells. Niclosamide is further shown to synergize with Sorafenib in suppressing RCC cell proliferation and survival. In the xenograft tumor model, Niclosamide is shown to effectively inhibit tumor growth and suppress RCC cell proliferation. Conclusions: Niclosamide may be repurposed as a potent anticancer agent, which can potentiate the anticancer activity of the other agents targeting different signaling pathways in the treatment of human RCC.

(C) 2018 The Author(s)

Published by S. Karger AG, Basel

\section{Introduction}

Renal cell carcinoma (RCC) is the most lethal of the urological cancers and accounts for about $3 \%$ of all malignancies in adults, with about 300, 000 new cases per year and about 120,000 deaths per year worldwide [1-3]. As it is most common in older men, active and passive cigarette smoking, obesity and hypertension are known risk factors although most patients do not have an identifiable risk factor; and the pathogenic mechanisms underlying the established risk factors remain unclear $[1,2]$. Nonetheless, about $2-3 \%$ of RCC are associated with familial and several autosomal dominant syndromes, most notably von Hippel-Lindau (VHL) syndrome [4] and hereditary papillary renal carcinoma (HPRC) [3, 5, 6]. While Patients with RCC can present with local or systemic symptoms, many cases are symptomless until the stage is advanced, including flank pain, blood in the urine, or a lump in the abdomen $[1,2]$. Pathologically, RCC comprises a heterogeneous group of cancers with diverse genetic and molecular alterations, each derived from the various parts of the nephron and possessing distinct genetic characteristics, histological features, and clinical phenotypes $[1,2,6,7]$. Clear cell renal cell carcinoma accounts for about $70-80 \%$ of all RCC while papillary RCC represents about $10-15 \%$ of renal cancer $[1,2]$. Other rare subtypes include papillary adenoma, multilocular cystic clear-cell carcinoma, hybrid oncocytic chromophobe tumor, carcinoma of the collecting ducts of Bellini, renal medullary carcinoma, carcinoma associated with neuroblastoma, and mucinous tubular and spindle-cell carcinoma [1-3]. Although RCC can be sporadic or hereditary, and VHL mutations only occur in a small fraction of RCC, a majority is driven by dysfunction of the von Hippel-Lindau (VHL) gene function, which leads to aberrant activation of the hypoxic response and neoangiogenesis $[2,3,7]$.

While nephrectomy remains an importafnt intervention for localized RCC, systemic therapy is the mainstay of treatment for the patients with relapsed and/or metastatic RCC $[1,8,9]$. Despite recent advances in diagnostic imaging, surgical therapy and basic molecular understanding, many patients still experience metastatic disease, and their response rates to conventional therapies rarely exceed $25 \%$, yet associated with serious adverse effects [1, $8,10]$. For the past decade, the therapeutic landscape of RCC has significantly expanded, mostly driven by targeting the dysregulated metabolic pathways involved in oxygen sensing (e.g., VHL/HIF pathway), energy sensing (e.g., HGF/MET pathway) and/or nutrient sensing cascade (e.g., AMPK-TSC1/2-mTOR and PI3K-Akt-mTOR pathways) [8-11]. For instance, small molecule inhibitors that target VEGF receptors (Sunitinib and Sorafenib) have a favorable toxicity profile and can prolong time to progression and preserve quality of life when used in newly diagnosed or previously treated patients $[8,9,12]$. Temsirolimus, an MTOR inhibitor, can prolong the survival of patients with poor-risk disease $[8,12]$. Nonetheless, responses to these drugs are partial and of limited duration in most cases $[8-10,12]$. Therefore, while new drugs, drug combinations and/or immunotherapies are undergoing clinical trials and may impact the treatment of RCC in future years, there is an unmet clinical need of alternative therapies for advanced RCC. 
Even though small molecule inhibitor-based targeted therapies have significantly expanded cancer therapy landscape [13-15], it is conceivable that repurposing current FDA-approved drugs may represent a rapid and cost-effective approach to developing new anticancer agents. In fact, several such drugs are at various stages of clinical trials [16, 17]. Niclosamide (trade name Niclocide), a teniacide in the anthelmintic family, has been approved for human use for nearly 50 years. Niclosamide was thought to inhibit oxidative phosphorylation and stimulates ATPase activity in the mitochondria of cestodes of tapeworm, killing the scolex and proximal segments of the tapeworm, which is well tolerated in humans $[18,19]$. Through various high-throughput screening campaigns, Niclosamide was identified as a potential anticancer agent [19], and showed effective anticancer activity in several types of human cancer [20-39]. Nonetheless, it is unlikely that Niclosamide may be used as a single agent therapy for human cancer.

In this study, we investigate whether Niclosamide exhibits anticancer activity and synergizes with the targeted therapy agent Sorafenib in suppressing cell proliferation of renal cancer cells. We find that Niclosamide is highly effective on inhibiting cell proliferation, cell migration and cell cycle progression, and inducing apoptosis in human renal cancer cells. Mechanistically, Niclosamide inhibits the expression of C-MYC and E2F1 while inducing the expression of PTEN, which may cause a feedback upregulation of PI3K/AKT/ mTOR expression in RCC cells. Niclosamide is further shown to synergize with Sorafenib in suppressing RCC cell proliferation and survival. Niclosamide effectively inhibits tumor growth and suppresses RCC cell proliferation in the xenograft tumor model of human RCC. Collectively, our findings strongly suggest that Niclosamide may be repurposed as potent anti-renal cancer agent and may become more efficacious when combined with agents that target other signaling pathways in the treatment of human RCC.

\section{Materials and Methods}

\section{Cell Culture and Chemicals}

Human renal cell carcinoma (RCC) lines A498 and Caki-1 were purchased from ATCC (Manassas, VA) and maintained in complete Dulbecco's Modified Eagle's Medium (DMEM) containing 10\% fetal bovine serum (FBS, Invitrogen, Carlsbad, CA), 100 units of penicillin and $100 \mu \mathrm{g}$ of streptomycin at $37^{\circ} \mathrm{Cin} 5 \% \mathrm{CO}_{2}$ [40-42]. Niclosamide was purchased from Cayman Chemical (Ann Arbor, MI). Sorafenib was purchased from Selleckchem (Houston, TX). Unless indicated otherwise, all chemicals were purchased from Sigma-Aldrich (St. Louis, MO) or ThermoFisher Scientific (Waltham, MA).

\section{Crystal violet cell viability assay}

Crystal violet staining assay was conducted as described [43, 44]. Briefly, subconfluent A498 and Caki1 cells were treated with varied concentrations of Niclosamide or DMSO control. At 72h after treatment, cells were washed with PBS and stained with $0.5 \%$ crystal violet/formalin solution at room temperature for 20-30min. The stained cells were rinsed with tape water and air dried for taking macrographic images [18]. For quantitative measurement, the stained cells were dissolved in $10 \%$ acetic acid at room temperature for $20 \mathrm{~min}$, followed by measuring absorbance at $570-590 \mathrm{~nm}[22]$.

\section{WST-1 cell proliferation assay}

Cell proliferation was assessed by using Premixed WST-1 Reagent (Clontech, Mountain View, CA) as described [18, 45]. Briefly, subconfluent A498 and Caki-1 cells were seeded in 96-well cell culture plates and treated with Niclosamide at the varied concentrations for $24 \mathrm{~h}, 48 \mathrm{~h}$ and $72 \mathrm{~h}$. The Premixed WST-1 Reagent was added to each well, followed by an incubation at $37^{\circ} \mathrm{C}$ for $60 \mathrm{~min}$ and reading at $440 \mathrm{~nm}$ using a microplate reader. Each assay condition was done in triplicate.

Cell wounding and migration assay

Cell wound healing migration assays were performed as previously described [45, 46]. Briefly, exponentially growing cells were seeded in 6-well cell culture plates at subconfluence. Once the cells 


\section{Cellular Physiology Cell Physiol Biochem 2018;47:957-971

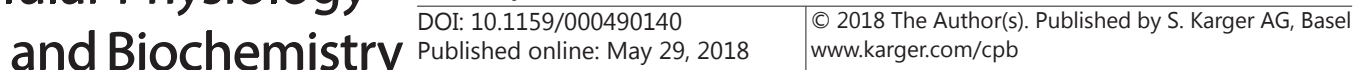

Yu et al.: Repurposing Niclosamide as Anti-RCC Agent

reached approximately $90 \%$ confluence, the monolayer cells were wounded with pipette tips and treated with various concentrations of Niclosamide. At various time points after wounding, the wound healing status at the approximately same fields was recorded under a bright field microscope. These assays were done in triplicate. The average gap widths were measured and determined from at least ten low-power field images for each assay condition using the Olympus Cellsens Digital Imaging software. The percentage of gap remaining open was calculated by dividing the average gap width at a given time point with the respective average gap width at $0 \mathrm{~h}$. Each assay condition was done in triplicate.

\section{Apoptosis analysis (Hoechst 33258 staining)}

As previously described $[47,48]$, exponentially growing A498 and Caki-1 cells were treated with $2 \mu \mathrm{M}$ Niclosamide or DMSO control. At 48h post treatment, cells were collected, fixed and stained with the Magic Solution (0.5\% NP-40, 3.4\% formaldehyde, $10 \mu \mathrm{g} / \mathrm{ml}$ Hoechst 33258 in PBS). Apoptotic cells were examined and recorded under a fluorescence microscope. Each assay condition was done in triplicate. The results were repeated at least in three independent batches of experiments. The average numbers of apoptotic cells were calculated by counting apparent apoptotic cells in at least ten random fields at 100x magnification for each assay.

\section{Cell cycle analysis}

As previously described [18], the exponentially growing A498 and Caki-1 cells were seeded in 6-well plates at subconfluence and treated with varied concentrations of Niclosamide or DMSO control. At 24h or $48 \mathrm{~h}$ post treatment, cells were collected, fixed and stained with the Magic Solution for $30 \mathrm{~min}$. The stained cells were subjected to flow cytometry analysis using the BD FACSCalibur-HTS. The acquired flow cytometry data were analyzed with the FlowJo v10.0 software. Each assay condition was done in triplicate.

\section{Total RNA isolation and touchdown-quantitative real-time PCR (TqPCR) analysis}

Exponentially growing A498 and Caki-1 cells were treated $1 \mu \mathrm{M}$ and $4 \mu \mathrm{M}$ Niclosamide or DMSO. At $24 \mathrm{~h}, 48 \mathrm{~h}$ and $72 \mathrm{~h}$ post treatment, total RNA was isolated from the treated cells by using TRIZOL Reagents (Invitrogen) and subjected to reverse transcription reactions with hexamer and M-MuLV Reverse Transcriptase (New England Biolabs, Ipswich, MA). The cDNA products were used as PCR templates. The qPCR primers were designed by using Primer3 program [49] and used to amplify the genes of interest. The primer sequences are as follows: GAPDH, ATGTTTTCCTGTGCCCTGAG and ATCTGTGGTGAGGGATGAGG; E2F1, ATGTTTTCCTGTGCCCTGAG and ATCTGTGGTGAGGGATGAGG; $c$-FOS, AGAATCCGAAGGGAAAGGAA and CTTCTCCTTCAGCAGGTTGG; C-MYC, CGTCCTGGGAAGGGAGAT and CGCTGCTATGGGCAAAGT; $c$-JUN, CAGGTGGCACAGCTTAAACA and TTTTTCTCTCCGTCGCAACT; AKT1, AGAAGCAGGAGGAGGAGGAG and TCTCCTTCACCAGGATCACC; PIK3CA, CCCCTCCATCAACTTCTTCA and CGGTTGCCTACTGGTTCAAT; MTOR, CCAGGCGGAGAACTTGCA and TGCGCAGGAAAGGCATGA; and PTEN, GTTTACCGGCAGCATCAAAT and CCCCCACTTTAGTGCACAGT. TqPCR reactions were carried out by using the SYBR Green-based qPCR analysis using a CFX-Connect unit (Bio-Rad Laboratories, Hercules CA) [50]. All TqPCR reactions were done in triplicate. GAPDH was used as a reference gene.

\section{Xenograft tumor formation and Xenogen bioluminescence imaging}

The use and care of animals were approved by the Institutional Animal Care and Use Committee. All experimental procedures were carried out in accordance with the approved guidelines. Briefly, Caki-1 cells were stably labeled with firefly luciferase (Caki-FLuc) with the piggyBac transposon system as previously described [51, 52]. Exponentially growing Caki-FLuc cells were collected, resuspended at $10^{7} \mathrm{cells} / \mathrm{ml}$ and injected subcutaneously into the flanks of athymic nude mice (Harlan Laboratories, 6-8 week old male, $10^{6}$ cells per injection, and 6 sites per mouse). At three days post injection, the mice were randomly divided into three groups ( $\mathrm{n}=5$ per group) and treated with various doses of Niclosamide $(10 \mathrm{mg}$ or $20 \mathrm{mg} / \mathrm{kg}$ body weight) or vehicle control (DMSO) intraperitoneally once every two days. Tumor growth was monitored by whole body bioluminescence imaging using Xenogen IVIS 200 Imaging System at 7, 14, 21, and 28 days post treatment. The average signal for each group at different time points was calculated using the Xenogen's Living Image analysis software as previously described [53-55]. 


\section{Cellular Physiology Cell Physiol Biochem 2018;47:957-971 \\ \begin{tabular}{l|l} 
and Biochemistry Published ontme: May 29, 2018 & $\begin{array}{l}\text { (c) } 2018 \text { The Author(s). Published by S. Karger AG, Basel } \\
\text { www.karger.com/cpb }\end{array}$
\end{tabular}}

Yu et al.: Repurposing Niclosamide as Anti-RCC Agent

$H \&$ E staining

The mice were sacrificed at the end of week 4, and subcutaneous tumor masses were retrieved, fixed in $10 \%$ buffered formalin and paraffin-embedded. Serial sections of the embedded specimens were stained with hematoxylin and eosin (H \& E) as described [56-58].

Immunohistochemical (IHC) staining

The IHC staining was performed as described [59-61]. Briefly, sections of the paraffin-embedded tissue blocks were deparaffinized, rehydrated, and subjected to immunohistochemical staining with anti-PCNA (Santa Cruz Biotechnology) antibody. Control IgG and minus primary antibodies were used as negative controls.

\section{Statistical analysis}

The quantitative assays were performed in triplicate and/or repeated three times. Data were expressed as mean \pm S.D. Statistical significances were determined by one-way analysis of variance and the student's $t$ test. A value of $\mathrm{p}<0.05$ was considered statistically significant.

\section{Results}

Niclosamide effectively inhibits cell proliferation of human renal cell carcinoma (RCC) cells

We first tested the effect of the antibiotic Niclosamide on the proliferative activity of two commonly-used human RCC lines A498 and Caki-1. Using the crystal violet staining assay, we found that cell proliferation was significantly inhibited by Niclosamide at as low as $2 \mu \mathrm{M}$ and $4 \mu \mathrm{M}$ in A498 and Caki-1, respectively (Fig. 1A-a). Quantitative analysis of the crystal violet staining studies indicates that Niclosamide significantly inhibited A498 and Caki- 1 cell proliferation at as low as $1 \mu \mathrm{M}$ and $2 \mu \mathrm{M}$, respectively $(\mathrm{p}<0.05)$ (Fig. $1 \mathrm{~A}-\mathrm{b})$. The growth inhibition activity of Niclosamide was further confirmed by the WST-1 proliferation assay (Fig. 1B). Specifically, the Niclosadmide-exerted inhibitory effect on cell proliferation in both A498 and Caki-1 cells was shown in a dose-dependent fashion, as well as in a timedependent manner (Fig. 1B). These results indicate that Niclosamide can effectively inhibit cell proliferation of human renal cancer cells.

Niclosamide inhibits cell migration and cell cycle progression while inducing apoptosis in human renal cancer cells

We next examined if Niclosamide exerts any effect on cell migration and wound healing in renal cancer cells. When the freshly confluent A498 monolayer was wounded, the gap was almost completely closed in DMSO control group at 36h, but the cells treated with $1 \mu \mathrm{M}$ or $4 \mu \mathrm{M}$ Niclosamide failed to close the gap at $24 \mathrm{~h}$ (Fig. 2A-a). Quantitatively, the average percentages of the gap remaining open were significantly higher in the Niclosamide treatment groups $(\mathrm{p}<0.01)$ (Fig. 2A-b). Similar results were obtained in Caki-1 cells, in which $1 \mu \mathrm{M}$ or $4 \mu \mathrm{M}$ Niclosamide was shown to effectively inhibit cell proliferation and gap closure (Fig. 2Bab). These results suggest that Niclosamide may significantly inhibit cell proliferation and migration.

We also performed cell cycle analysis on Niclosamide-treated cells and found a significant decrease in numbers of cells in S/M/G2 phases in both $1 \mu \mathrm{M}$ and $4 \mu \mathrm{M}$ Niclosamide-treated A498 cells relative to the controls (Fig. 3A-a). Similar results were obtained in Niclosamidetreated Caki-1 cells (Fig. 3A-b). Most notably, a significant portion of the Niclosamidetreated cells in both lines, especially at $4 \mu \mathrm{M}$ Niclosamide, appeared in sub-G1 phase (Fig. $3 \mathrm{~A}$ ), suggesting Niclosamide may induce apoptosis. Thus, we investigated if Niclosamide can induce apoptosis in renal cancer cells. When A498 and Caki-1 cells were treated with $0 \mu \mathrm{M}$ or $2 \mu \mathrm{M}$ Niclosamide for $72 \mathrm{~h}$ and stained with Hoechst 33258, significant numbers of apoptotic cells were observed (Fig. 3B-a). Quantitative analysis indicated that the percentages of apoptotic cells were significantly increased in Niclosamide treated A498 and Caki-1 cells $(\mathrm{p}<0.01)$ (Fig. 3B-b). Collectively, these results suggest that Niclosamide's inhibitory effect 
Fig. 1. Niclosamide inhibits the proliferation of human renal cell carcinoma (RCC) cells. (A) Exponentially growing A498 and Caki-1 cells were seeded in 12well cell culture plates and treated with the indicated concentrations of niclosamide for $72 \mathrm{~h}$. The viable cells were fixed and stained with Crystal violet (a). For quantitative determination, the stained cells were dissolved in acetic acid and subjected to absorbance reading at 570nm (b). Each assay condition was done in triplicate and the results were repeated at least in three independent batches of experiments. Representative results are shown. "*” $\mathrm{p}<0.05$, “**” $\mathrm{p}<0.01$, compared with the DMSO control groups. (B) WST-1 cell proliferation assay. Subconfluent A498 and Caki-1 cells were seeded in 96-well plates and treated with Niclosamide (NA) at the indicated concentrations. At the indicated time points post treatment, the WST-1 reagent was added to plates and incubated for $3 \mathrm{~h}$ and absorbance measurement was

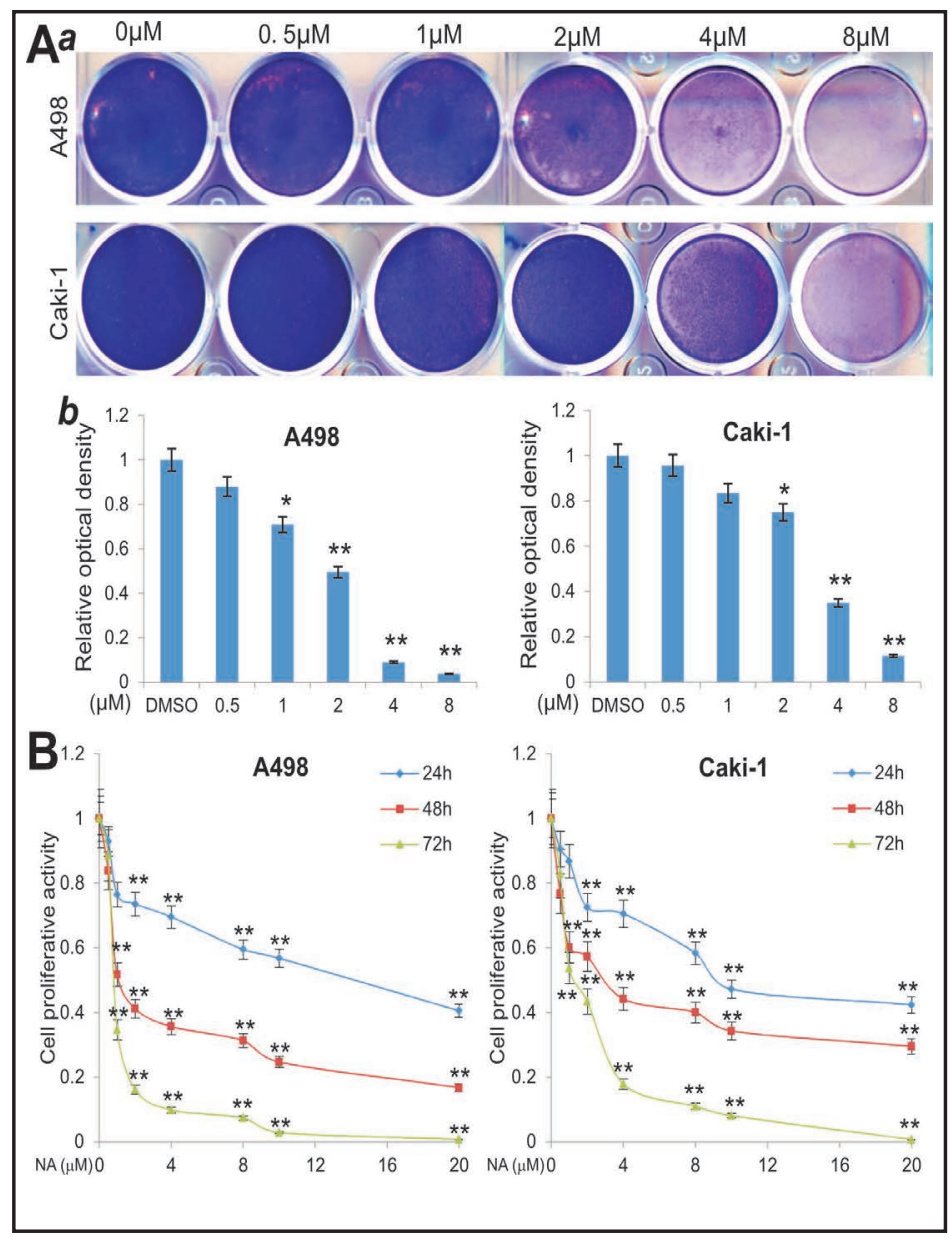
performed. All assay conditions were done in triplicate. “**” $\mathrm{p}<0.01$, compared with the DMSO control groups.

on renal cancer cell proliferation may be due in part to inhibition of cell cycle progression and induction of apoptosis.

\section{Niclosamide inhibits multiple cancer-related signaling pathways and synergizes with Sorafenib in inhibiting the proliferation of human RCC cells}

It has been reported that Niclosamide may exert anti-cancer activity in cancer cells by inhibiting Wnt/ $\beta$-catenin activity [62], as Wnt/ $\beta$-catenin signaling may play an important role in cancer development [63-65]. We previously reported that Niclosamide inhibits multiple cancer-related pathways in osteosarcoma cells and ovarian cancer cells [21, 22]. Here, we analyzed the effect of Niclosamide on several selected pathways. When A498 and Caki-1 cells were treated various concentrations of Niclosamide, the expression of both C-MYC and E2F1 was significantly inhibited in a dose-dependent fashion although the expression of FOS and JUN was not apparently affected (Fig. 4A).

We further examined the effect of Niclosamide on PI3K pathway. We found that the expression of PTEN was significantly up-regulated by Niclosamide in both A498 and Caki-1 cells (Fig. 4B-ab). Surprisingly, the expression of PIK3CA and MTOR, to a lesser extent AKT1, was also elevated in Niclosamide-treated A498 and Caki-1 cells (Fig. 4B-ab). While the exact mechanism underlying the up-regulation of PI3K pathway is not known, it is conceivable that Niclosamide-induced expression of PTEN may lead to up-regulation of PI3K pathway through a negative feedback fashion, or vice versa. Nonetheless, these results suggest that Niclosamide may significantly impact PI3K signaling pathway in renal cancer cells. 
Fig. 2. Niclosamide inhibits the cell migration and wounding closure of human RCC cells. Exponentially growing A498 (A) and Caki-1 (B) cells were seeded in 6-well cell culture plates. Once cells reached confluence, cell wounding was created with pipet tips and then treated with $1.0 \mu \mathrm{M}$, $4 \mu \mathrm{M}$ niclosamide or DMSO vehicle control. The wound closure status was monitored and recorded at the indicated time points (a). Each assay condition was done in triplicate. The results were repeated at least in three independent batches of experiments. Representative results are shown. Quantitatively, the average gap widths were measured and determined from at least ten low-power field images for

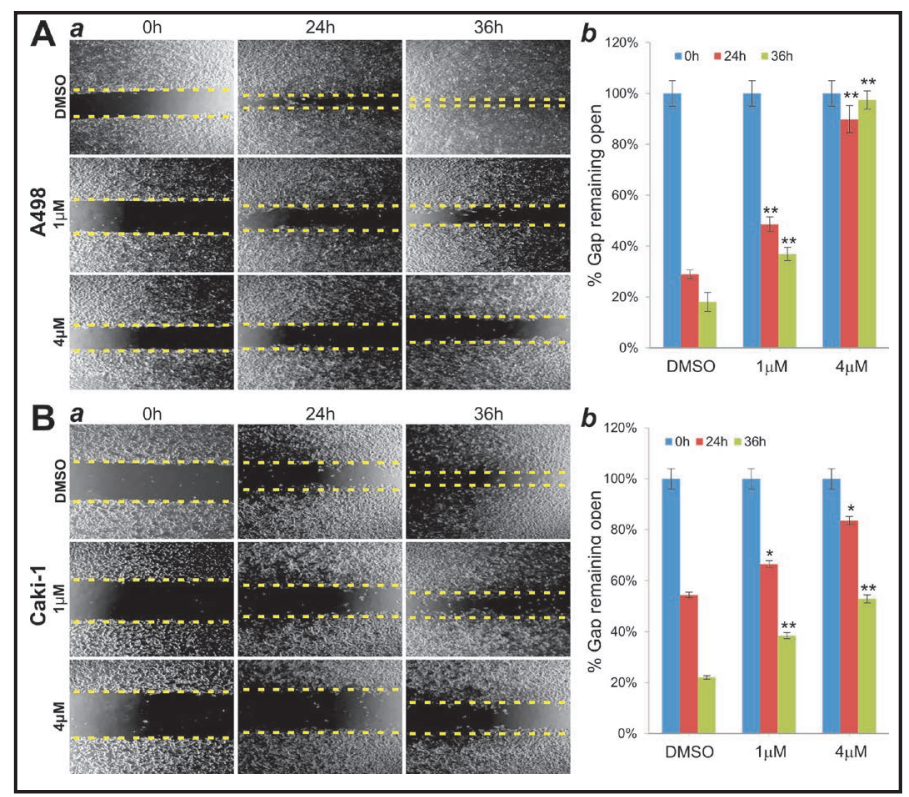
each assay condition using Olympus

Cellsens Digital Imaging software. The percentage of gap remaining open was calculated by dividing the average gap width at a given time point with the respective average gap width at $0 \mathrm{~h}(\mathrm{~b})$. " *” $\mathrm{p}<0.05$, , “*” $\mathrm{p}<0.01$ (compared with the control group).

Fig. 3. Niclosamide effectively inhibits cell cycle progression and induces apoptosis of human RCC cells. (A) Cell cycle analysis. Subconfluent A498 (a) and Caki1 (b) cells were treated with Niclosamide or vehicle control for $24 \mathrm{~h}$ or $48 \mathrm{~h}$. Cells were collected, fixed, stained with Hoechst 33258, and subjected to FACS analysis. Percentages of cells in non-G1 phase were tabulated and graphed. Each assay condition was done in triplicate. (B) Exponentially growing A498 and Caki-1 cells were treated with $2 \mu \mathrm{M}$ Niclosamide or DMSO control $(0 \mu \mathrm{M})$. At $72 \mathrm{~h}$ post treatment, cells were collected, fixed and stained with Hoechst 33258. Apoptotic cells (indicated by yellow arrows) were recorded under a fluorescence microscope (a). Each assay condition was done in triplicate. Apparent apoptotic cells were counted in at least 10 random fields under high-power magnification (b). “**” $\mathrm{p}<0.01$

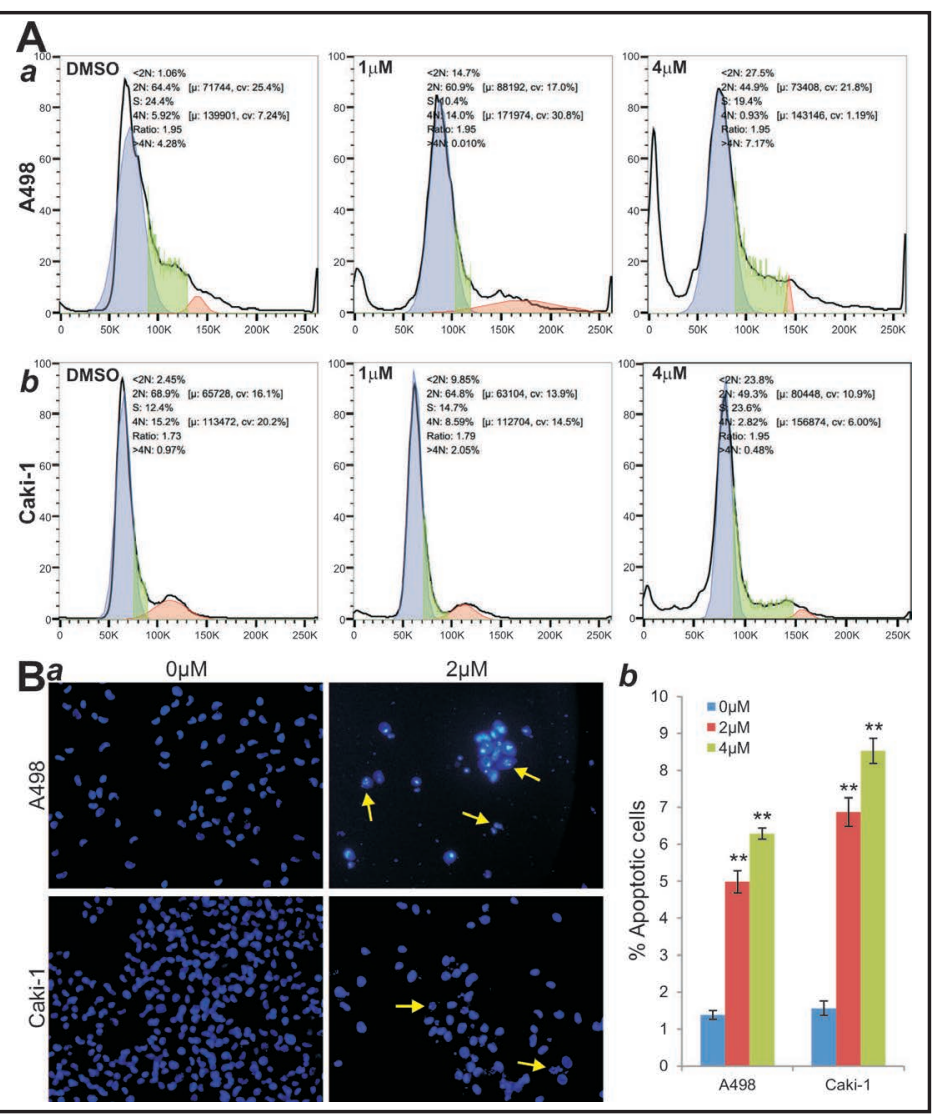
(Niclosamide treated vs. control group).

\section{KARGER}


Fig. 4. Niclosamide may target multiple cellular pathways in human renal cell carcinoma cells. Exponentially growing A498 and Caki-1 cells were treated with $1.0 \mu \mathrm{M}$ and $4.0 \mu \mathrm{M}$ niclosamide or DMSO. At $72 \mathrm{~h}$ post treatment, total RNA was isolated and subjected to TqPCR analysis using primers specific for C-MYC, E2F1, C-FOS and C-JUN (A) or PTEN, PIK3CA, AKT1 and MTOR (B). All samples were normalized with endogenous GAPDH levels. Each assay condition was done in triplicate. “**”, $\mathrm{p}<0.01$ (compared with that of the DMSO or $0.0 \mu \mathrm{M}$ control groups).
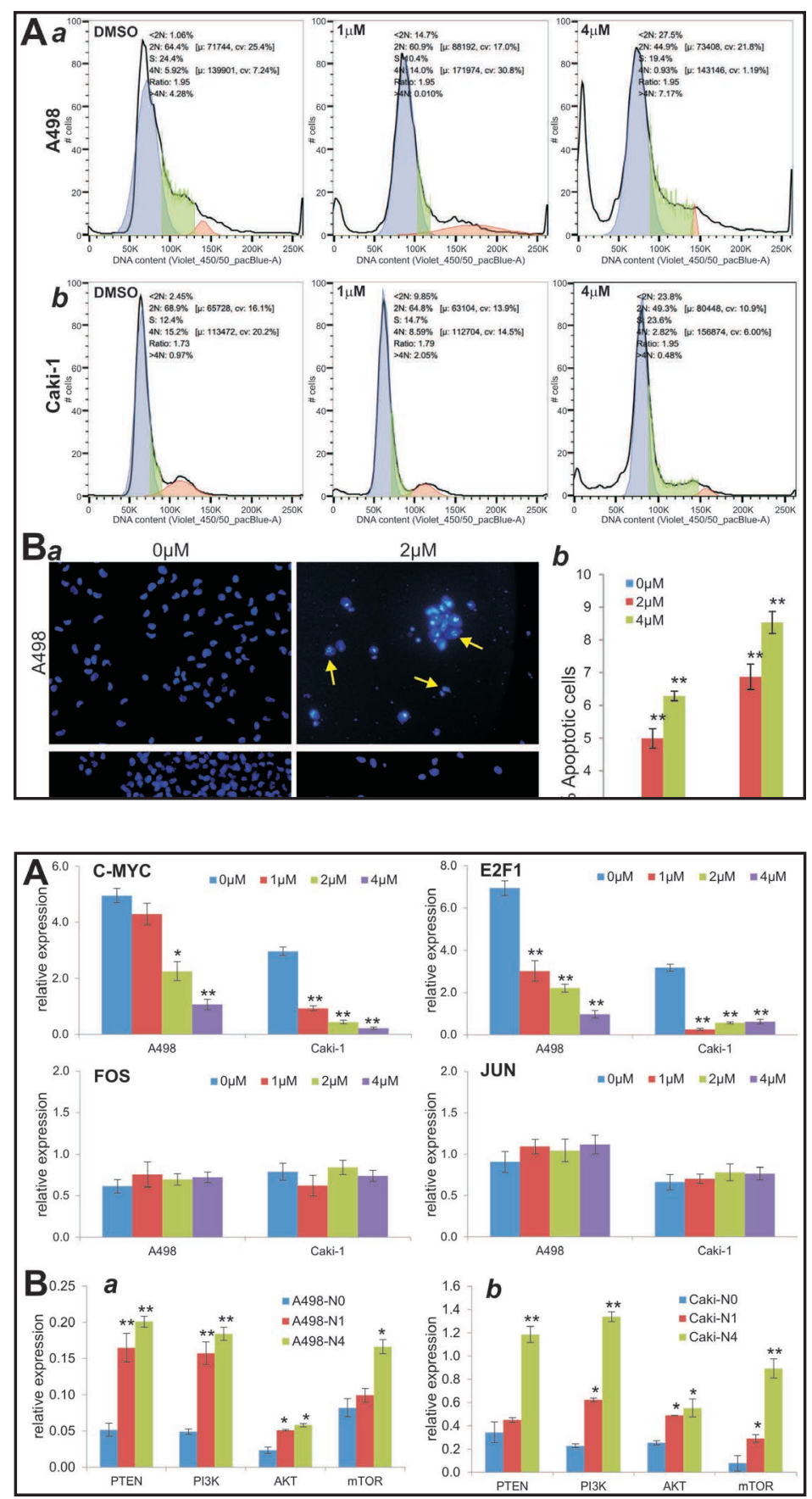

Fig. 5. Niclosamide synergizes with sorafenib in inhibiting the proliferation of human RCC cells. Exponentially growing A498 (A) and Caki-1 (B) cells were seeded in 12-well cell culture plates and treated with the indicated concentrations of niclosamide or sorafenib (SOR), or with varied concentrations of niclosamide at the $10 \mu \mathrm{M}$ sorafenib. At $72 \mathrm{~h}$ post treatment, the viable cells were fixed and stained with Crystal violet. Each assay condition was done in triplicate. Representative results are shown.

As several targeted therapies including Sorafenib have been approved as alternative therapies for renal cancer, we examined whether Niclosamide would synergize with these targeted therapies in renal cancer cells. In A498 cells, we found that Sorafenib exhibited significant cytotoxicity at $20 \mu \mathrm{M}$, while no apparent cell death was observed at $10 \mu \mathrm{M}$ (Fig. $5 \mathrm{~A}$ ). However, in the presence of Niclosamide at as low as $0.25 \mu \mathrm{M}$ significant cytotoxicity was observed, and complete cell death was obtained at $>0.5 \mu \mathrm{M}$ Niclosamide at the sub-lethal concentration of $10 \mu \mathrm{M}$ Sorafenib (Fig. 5A). Similar results were obtained in Caki-1 cells as Niclosamide was shown to significantly enhance the cytotoxicity of sub-lethal concentration of $10 \mu \mathrm{M}$ Sorafenib (Fig. 5B). These results strongly suggest that Niclosamide may synergize with Sorafenib to enhance its cytotoxicity against renal cancer cells. 


\section{Cellular Physiology Cell Physiol Biochem 2018;47:957-971 \begin{tabular}{ll|l} 
DOI: 10.1159/000490140 & $\begin{array}{l}\text { O 2018 The Author(s). Published by S. Karger AG, Basel } \\
\text { www.karger.com/cpb }\end{array}$ \\
\hline
\end{tabular}

Niclosamide inhibits RCC xenograft tumor growth and tumor cell proliferation in vivo

We tested the in vivo anticancer activity of Niclosamide using the xenograft tumor model of human renal cancer cells. Firefly luciferase-labeled Caki-1 cells were injected subcutaneously into the flanks of athymic nude mice, and treated with Niclosamide at three different doses $(10 \mathrm{mg} / \mathrm{kg}$ and $20 \mathrm{mg} / \mathrm{kg}$ or DMSO vehicle control) intraperitoneally once every two days. Whole body optical imaging indicated that, while the xenograft tumors continued to grow over the 4-week testing period, the tumor growth was significantly inhibited after a 2 -week treatment at $20 \mathrm{mg} / \mathrm{kg}$ and a 4 -week treatment at $10 \mathrm{mg} / \mathrm{kg}$, respectively (Fig. 6A-a), which were quantitatively analyzed and shown statistically significant $(\mathrm{p}<0.01)$ (Fig. 6A-b). Consistent with the optical imaging results, the retrieved tumor volumes at the endpoint were significantly reduced in both Niclosamide treatment groups, compared with that of the control group ( $\mathrm{p}<0.01$ ) (Fig. 6B-a), as shown in the gross images (Fig. 6B-b \& c).

$\mathrm{H} \& \mathrm{E}$ staining of the retrieved tumor samples revealed that while the control group exhibited high cellular proliferation, Niclosamide treated tumor samples exhibited extensive necrosis (Fig. 7A). Immunohistochemical staining of the cell proliferation marker PNCA indicated that the Niclosamide-treated samples retrieved from the $10 \mathrm{mg} / \mathrm{kg}$ group exhibited significantly decreased expression of PCNA, and almost no PCNA expression was detected in the $20 \mathrm{mg} / \mathrm{kg}$ group, whereas the tumors retrieved from the control group exhibited a high level of PCNA expression (Fig. 7B). Quantitative analysis indicated that approximately $>93 \%$ of the tumor cells were PCNA-negative non-proliferative cells in the $20 \mathrm{mg} / \mathrm{kg}$ treatment group. Thus, these results further confirm that Niclosamide can effectively inhibit renal cancer cell proliferation in vivo, which may at least in part account for its anticancer activity.

Fig. 6. Niclodsamide inhibits the growth of xenograft tumor of human renal cell carcinoma cells in athymic nude mice. (A) Xenogen bioluminescence imaging of xenograft tumor growth. Firefly luciferase-labeled Caki-1 cells were injected subcutaneously into athymic nude mice, and treated with niclosamide $10 \mathrm{mg} / \mathrm{kg}$ and $20 \mathrm{mg} / \mathrm{kg}$ or DMSO vehicle control at day 3 (indicated by an arrow), intraperitoneally once every two days. The mice were imaged at 3 (D3), 7 (D7), 14 (D14) and 28 (D28) days after drug treatment. Representative images are shown (a). The imaging data for day 21 are not shown. The average signal for each group at different time points were calculated using the Xenogen's Living Image analysis software (b). “**” $\mathrm{p}<0.01$ (treatment vs. control groups). (B) (a) the average tumor volume for each group. ${ }^{* *} \mathrm{p}<0.01$ (treatment vs. control groups). (b \& c)

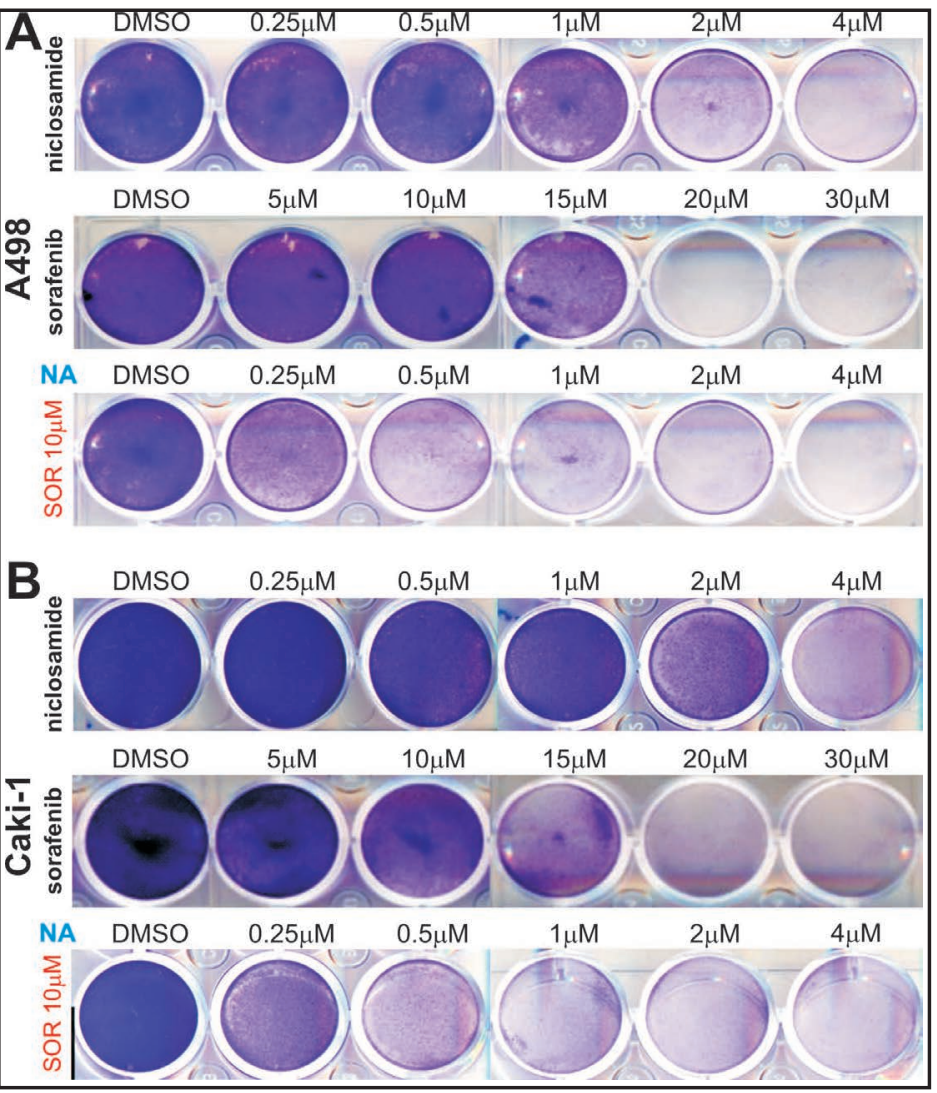
Representative gross images of the retrieved tumor samples. 
Fig. 7. Niclodsamide inhibits the proliferative activity of human renal cell carcinoma cells in vivo. (A) $\mathrm{H}$ \& E staining. The retrieved tumor samples from each group were paraffin-embedded, sectioned and subjected to $\mathrm{H} \& \mathrm{E}$ staining. (B) PCNA immunohistochemistry. Tumor sections were also subjected to immunohistochemical staining using anti-PCNA antibody. Control IgGs were used as negative controls (not shown). Representative images are shown.

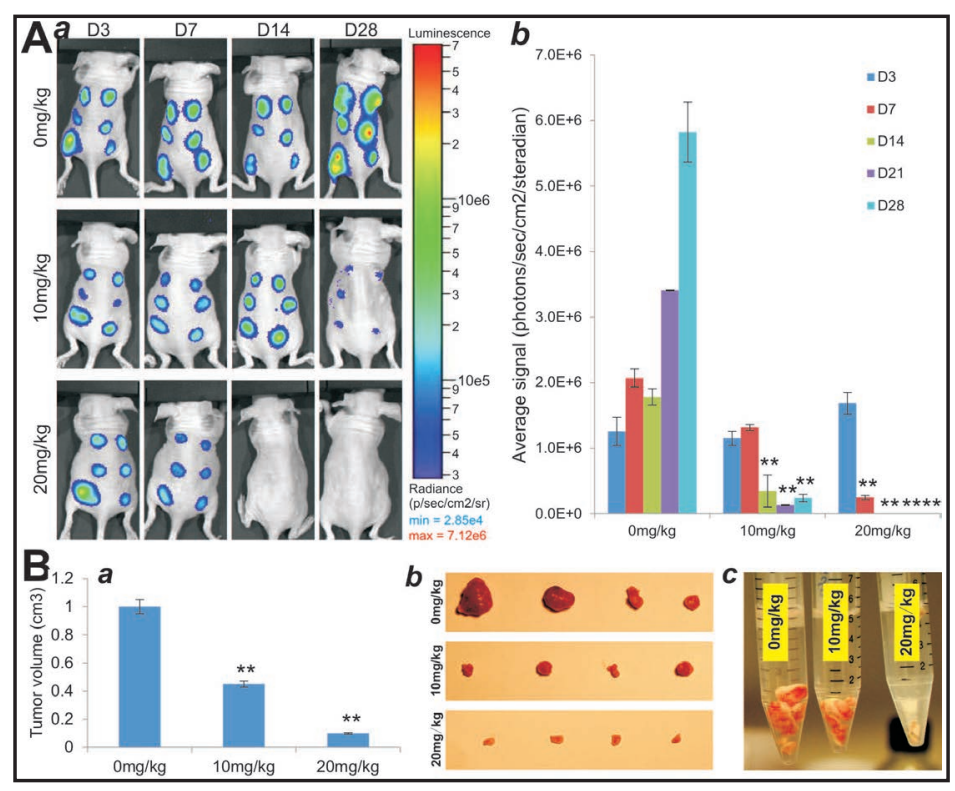

\section{Discussion}

Even though considerable progress has been made in the treatment of RCC with the development of innovative surgical and systemic strategies [1, 8, 9], efficacious therapeutic options for metastatic renal cell carcinoma and/or relapsed RCC remain limited. Here, we demonstrated that the anthelmintic agent Niclosamide potently inhibits cell proliferation, cell migration and cell cycle progression, and induces apoptosis in human renal cancer cells. Mechanistically, Niclosamide was shown to inhibit the expression of C-MYC and E2F1 while inducing the expression of PTEN, which may lead to a feedback upregulation of PI3K/AKT/ mTOR expression in RCC cells. Niclosamide is further shown to synergize with Sorafenib in suppressing RCC cell proliferation and survival. In the xenograft tumor model of human RCC, Niclosamide effectively inhibits tumor growth and suppresses RCC cell proliferation. Thus, our findings strongly suggest that Niclosamide may be repurposed as a potent anticancer agent and combine with inhibitors that target other signaling pathways in the treatment of human renal cell cancer.

Niclosamide has been shown to exhibit anticancer activity in several types of human cancer [19, 20, 23, 24], osteosarcoma [21], lung cancer [25, 26], breast cancer [27-30], prostate cancer [27, 31], glioblastoma [32], head and neck cancer [33], leukemia [34, 35], human uterine leiomyoma [36], and ovarian cancer [37-39]. We previously showed that Niclosamide exerts its anticancer activity by targeting multiple signaling pathways in human osteosarcoma [21]. More recently, we have demonstrated that the anticancer activity of Niclosamide can be potentiated by inhibiting IGF signaling in human ovarian cancer cells [22]. In this study, we demonstrate that Niclosamide exhibits anticancer activity and synergizes with the targeted therapy agent Sorafenib in suppressing cell proliferation of renal cancer cells. It was recently reported that autophagy may play an important role in Sorafenib resistance in lver cancer [66]. It would be interesting to investigate whether Niclosamide would exert any effects on autophagy in renal cancer. Overall, the molecular underpinning of Niclosamide-mediated anticancer activity remains to be fully elucidated although several studies have been carried out to delineate its potential molecular mechanisms [19].

It is conceivable that, in addition to Sorafenib, Niclosamide may potentiate or sensitize the anticancer activities of other currently-approved targeted therapies for RCC. The targeted drugs used to treat advanced RCC function by blocking angiogenesis or tyrosine kinases that help RCC cells grow and survive. As clear cell RCC usually harbors mutations or inactivation of VHL gene and resultant overexpression of VEGF, the first drug to validate VEGF 


\section{Cellular Physiology Cell Physiol Biochem 2018;47:957-971

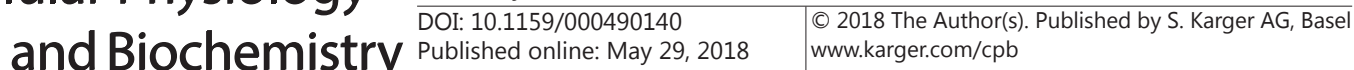 \\ Yu et al.: Repurposing Niclosamide as Anti-RCC Agent}

as a target in the treatment of clear cell RCC was the monoclonal antibody bevacizumab or Avastin [67]. Like Sorafenib, Sunitinib blocks several tyrosine kinases and attacks both blood vessel growth and other targets that help cancer cells grow. Other tyrosine kinase and/or neoangiogenesis inhibitors for RCC therapies include Pazopanib (Votrient), Axitinib (Inlyta), Cabozantinib (Cabometyx), and Lenvatinib (Lenvima). The mTOR is another validated therapeutic target as the mTOR inhibitors Temsirolimus and Everolimus have been shown to prolong progression-free survival in first-line treatment of poor prognosis RCC. Therefore, it is of translational significance to investigate whether Niclosamide can potentiate or augment the anticancer activity of these targeted therapies for RCC.

In summary, we demonstrate that Niclosamide effectively inhibit cell proliferation, cell migration and cell cycle progression, and induces apoptosis in human RCC cells. Niclosamide synergizes with Sorafenib in suppressing RCC cell proliferation and survival. Furthermore, Niclosamide effectively inhibits tumor growth and suppresses RCC cell proliferation in the xenograft tumor model of human RCC. Taken together, our findings strongly suggest that Niclosamide may be repurposed as potent anticancer agent and may potentiate the anticancer activity of other targeted therapies in the treatment of human renal cell cancer.

\section{Acknowledgements}

The reported work was supported in part by research grants from the National Institutes of Health (CA226303 to TCH), and the National Key Research and Development Program of China (2016YFC1000803 and 2011CB707906 to TCH). This project was also supported in part by The University of Chicago Cancer Center Support Grant (P30CA014599) and the National Center for Advancing Translational Sciences of the National Institutes of Health through Grant Number UL1 TR000430. Funding sources were not involved in the study design; in the collection, analysis and interpretation of data; in the writing of the report; and in the decision to submit the paper for publication.

\section{Disclosure Statement}

The authors declare to have no conflict of interests.

\section{References}

1 Rini BI, Campbell SC, Escudier B: Renal cell carcinoma. Lancet 2009;373:1119-1132.

-2 Capitanio U, Montorsi F: Renal cancer. Lancet 2016;387:894-906.

-3 Srinivasan R, Ricketts CJ, Sourbier C, Linehan WM: New strategies in renal cell carcinoma: targeting the genetic and metabolic basis of disease. Clin Cancer Res 2015;21:10-17.

-4 Linehan WM, Vasselli J, Srinivasan R, Walther MM, Merino M, Choyke P, Vocke C, Schmidt L, Isaacs JS, Glenn G, Toro J, Zbar B, Bottaro D, Neckers L: Genetic basis of cancer of the kidney: disease-specific approaches to therapy. Clin Cancer Res 2004;10:6282S-6289S.

5 Linehan WM, Pinto PA, Bratslavsky G, Pfaffenroth E, Merino M, Vocke CD, Toro JR, Bottaro D, Neckers L, Schmidt LS, Srinivasan R: Hereditary kidney cancer: unique opportunity for disease-based therapy. Cancer 2009;115:2252-2261.

6 Linehan WM, Srinivasan R, Schmidt LS: The genetic basis of kidney cancer: a metabolic disease. Nat Rev Urol 2010;7:277-285.

7 Su D, Singer EA, Srinivasan R: Molecular pathways in renal cell carcinoma: recent advances in genetics and molecular biology. Curr Opin Oncol 2015;27:217-223.

8 Ciccarese C, Brunelli M, Montironi R, Fiorentino M, Iacovelli R, Heng D, Tortora G, Massari F: The prospect of precision therapy for renal cell carcinoma. Cancer Treat Rev 2016;49:37-44. 


\section{Cellular Physiology Cell Physiol Biochem 2018;47:957-971 \begin{tabular}{cl|l} 
DOI: 10.1159/000490140 & O 2018 The Author(s). Published by S. Karger AG, Basel \\
www.karger.com/cpb
\end{tabular}}

Yu et al.: Repurposing Niclosamide as Anti-RCC Agent

9 Posadas EM, Limvorasak S, Figlin RA: Targeted therapies for renal cell carcinoma. Nat Rev Nephrol 2017;13:496-511.

10 Jones J, Libermann TA: Genomics of renal cell cancer: the biology behind and the therapy ahead. Clin Cancer Res 2007;13:685s-692s.

11 Massari F, Ciccarese C, Santoni M, Brunelli M, Piva F, Modena A, Bimbatti D, Fantinel E, Santini D, Cheng L, Cascinu S, Montironi R, Tortora G: Metabolic alterations in renal cell carcinoma. Cancer Treat Rev 2015;41:767-776.

12 Costa LJ, Drabkin HA: Renal cell carcinoma: new developments in molecular biology and potential for targeted therapies. Oncologist 2007;12:1404-1415.

13 Sawyers C: Targeted cancer therapy. Nature 2004;432:294-297.

14 Huang M, Shen A, Ding J, Geng M: Molecularly targeted cancer therapy: some lessons from the past decade. Trends Pharmacol Sci 2014;35:41-50.

15 Baudino TA: Targeted Cancer Therapy: The Next Generation of Cancer Treatment. Curr Drug Discov Technol 2015;12:3-20.

16 Gupta SC, Sung B, Prasad S, Webb LJ, Aggarwal BB: Cancer drug discovery by repurposing: teaching new tricks to old dogs. Trends Pharmacol Sci 2013;34:508-517.

17 Wang ZY, Quan Y, Zhang HY: Medical genetic inspirations for anticancer drug repurposing. Trends Pharmacol Sci 2014;35:1-3.

18 Deng Y, Zhang J, Wang Z, Yan Z, Qiao M, Ye J, Wei Q, Wang J, Wang X, Zhao L, Lu S, Tang S, Mohammed MK, Liu H, Fan J, Zhang F, Zou Y, Liao J, Qi H, Haydon RC, Luu HH, He TC, Tang L: Antibiotic monensin synergizes with EGFR inhibitors and oxaliplatin to suppress the proliferation of human ovarian cancer cells. Sci Rep 2015;5:17523.

19 Li Y, Li PK, Roberts MJ, Arend RC, Samant RS, Buchsbaum DJ: Multi-targeted therapy of cancer by niclosamide: A new application for an old drug. Cancer Lett 2014;349:8-14.

20 Chen W, Chen M, Barak LS: Development of small molecules targeting the Wnt pathway for the treatment of colon cancer: a high-throughput screening approach. Am J Physiol Gastrointest Liver Physiol 2010;299:G293-300.

21 Liao Z, Nan G, Yan Z, Zeng L, Deng Y, Ye J, Zhang Z, Qiao M, Li R, Denduluri S, Wang J, Wei Q, Geng N, Zhao L, Lu S, Wang X, Zhou G, Luu HH, Haydon RC, He TC, Wang Z: The Anthelmintic Drug Niclosamide Inhibits the Proliferative Activity of Human Osteosarcoma Cells by Targeting Multiple Signal Pathways. Curr Cancer Drug Targets 2015;15:726-738.

-22 Deng Y, Wang Z, Zhang F, Qiao M, Yan Z, Wei Q, Wang J, Liu H, Fan J, Zou Y, Liao J, Hu X, Chen L, Yu X, Haydon RC, Luu HH, Qi H, He TC, Zhang J: A Blockade of IGF Signaling Sensitizes Human Ovarian Cancer Cells to the Anthelmintic Niclosamide-Induced Anti-Proliferative and Anticancer Activities. Cell Physiol Biochem 2016;39:871-888.

23 Osada T, Chen M, Yang XY, Spasojevic I, Vandeusen JB, Hsu D, Clary BM, Clay TM, Chen W, Morse MA, Lyerly HK: Antihelminth compound niclosamide downregulates Wnt signaling and elicits antitumor responses in tumors with activating APC mutations. Cancer Res 2011;71:4172-4182.

-24 Sack U, Walther W, Scudiero D, Selby M, Kobelt D, Lemm M, Fichtner I, Schlag PM, Shoemaker RH, Stein U: Novel effect of antihelminthic Niclosamide on S100A4-mediated metastatic progression in colon cancer. J Natl Cancer Inst 2011;103:1018-1036.

25 Li R, Hu Z, Sun SY, Chen ZG, Owonikoko TK, Sica GL, Ramalingam SS, Curran WJ, Khuri FR, Deng X: Niclosamide overcomes acquired resistance to erlotinib through suppression of STAT3 in non-small cell lung cancer. Mol Cancer Ther 2013;12:2200-2212.

26 You S, Li R, Park D, Xie M, Sica GL, Cao Y, Xiao ZQ Deng X: Disruption of STAT3 by niclosamide reverses radioresistance of human lung cancer. Mol Cancer Ther 2014;13:606-616.

27 Lu W, Lin C, Roberts MJ, Waud WR, Piazza GA, Li Y: Niclosamide suppresses cancer cell growth by inducing Wnt co-receptor LRP6 degradation and inhibiting the Wnt/beta-catenin pathway. PLoS One 2011;6:e29290.

28 Wang YC, Chao TK, Chang CC, Yo YT, Yu MH, Lai HC: Drug screening identifies niclosamide as an inhibitor of breast cancer stem-like cells. PLoS One 2013;8:e74538.

29 Ye T, Xiong Y, Yan Y, Xia Y, Song X, Liu L, Li D, Wang N, Zhang L, Zhu Y, Zeng J, Wei Y, Yu L: The anthelmintic drug niclosamide induces apoptosis, impairs metastasis and reduces immunosuppressive cells in breast cancer model. PLoS One 2014;9:e85887. 


\section{Cellular Physiology Cell Physiol Biochem 2018;47:957-971

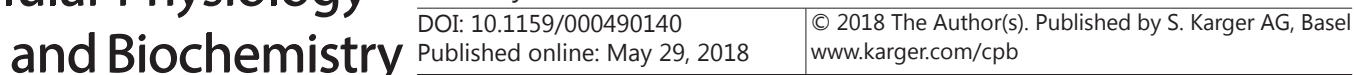

Yu et al.: Repurposing Niclosamide as Anti-RCC Agent

30 Londono-Joshi AI, Arend RC, Aristizabal L, Lu W, Samant RS, Metge BJ, Hidalgo B, Grizzle WE, Conner M, Forero-Torres A, Lobuglio AF, Li Y, Buchsbaum DJ: Effect of niclosamide on basal-like breast cancers. Mol Cancer Ther 2014;13:800-811.

-31 Liu C, Lou W, Zhu Y, Nadiminty N, Schwartz CT, Evans CP, Gao AC: Niclosamide inhibits androgen receptor variants expression and overcomes enzalutamide resistance in castration-resistant prostate cancer. Clin Cancer Res 2014;20:3198-3210.

-32 Wieland A, Trageser D, Gogolok S, Reinartz R, Hofer H, Keller M, Leinhaas A, Schelle R, Normann S, Klaas L, Waha A, Koch P, Fimmers R, Pietsch T, Yachnis AT, Pincus DW, Steindler DA, Brustle O, Simon M, Glas M, Scheffler B: Anticancer effects of niclosamide in human glioblastoma. Clin Cancer Res 2013;19:4124-4136.

-33 Li R, You S, Hu Z, Chen ZG, Sica GL, Khuri FR, Curran WJ, Shin DM, Deng X: Inhibition of STAT3 by niclosamide synergizes with erlotinib against head and neck cancer. PLoS One 2013;8:e74670.

34 Wang AM, Ku HH, Liang YC, Chen YC, Hwu YM, Yeh TS: The autonomous notch signal pathway is activated by baicalin and baicalein but is suppressed by niclosamide in K562 cells. J Cell Biochem 2009;106:682-692.

35 Jin Y, Lu Z, Ding K, Li J, Du X, Chen C, Sun X, Wu Y, Zhou J, Pan J: Antineoplastic mechanisms of niclosamide in acute myelogenous leukemia stem cells: inactivation of the NF-kappaB pathway and generation of reactive oxygen species. Cancer Res 2010;70:2516-2527.

36 Ono M, Yin P, Navarro A, Moravek MB, Coon VJ, Druschitz SA, Gottardi CJ, Bulun SE: Inhibition of canonical WNT signaling attenuates human leiomyoma cell growth. Fertil Steril 2014;101:1441-1449.

-37 Yo YT, Lin YW, Wang YC, Balch C, Huang RL, Chan MW, Sytwu HK, Chen CK, Chang CC, Nephew KP, Huang T, Yu MH, Lai HC: Growth inhibition of ovarian tumor-initiating cells by niclosamide. Mol Cancer Ther 2012;11:1703-1712.

-38 King ML, Lindberg ME, Stodden GR, Okuda H, Ebers SD, Johnson A, Montag A, Lengyel E, MacLean Ii JA, Hayashi K: WNT7A/beta-catenin signaling induces FGF1 and influences sensitivity to niclosamide in ovarian cancer. Oncogene 2015;34:3452-3462.

-39 Arend RC, Londono-Joshi AI, Samant RS, Li Y, Conner M, Hidalgo B, Alvarez RD, Landen CN, Straughn JM, Buchsbaum DJ: Inhibition of Wnt/beta-catenin pathway by niclosamide: a therapeutic target for ovarian cancer. Gynecol Oncol 2014;134:112-120.

40 Liao J, Wei Q, Fan J, Zou Y, Song D, Liu J, Liu F, Ma C, Hu X, Li L, Yu Y, Qu X, Chen L, Yu X, Zhang Z, Zhao C, Zeng Z, Zhang R, Yan S, Wu T, Wu X, Shu Y, Lei J, Li Y, Zhang W, Wang J, Reid RR, Lee MJ, Huang W, Wolf JM, He TC, Wang J: Characterization of retroviral infectivity and superinfection resistance during retrovirus-mediated transduction of mammalian cells. Gene Ther 2017;24:333-341.

41 Fan J, Wei Q Liao J, Zou Y, Song D, Xiong D, Ma C, Hu X, Qu X, Chen L, Li L, Yu Y, Yu X, Zhang Z, Zhao C, Zeng Z, Zhang R, Yan S, Wu T, Wu X, Shu Y, Lei J, Li Y, Zhang W, Haydon RC, Luu HH, Huang A, He TC, Tang H: Noncanonical Wnt signaling plays an important role in modulating canonical Wnt-regulated stemness, proliferation and terminal differentiation of hepatic progenitors. Oncotarget 2017;8:27105-27119.

-42 Wen S, Zhang H, Li Y, Wang N, Zhang W, Yang K, Wu N, Chen X, Deng F, Liao Z, Zhang J, Zhang Q, Yan Z, Liu W, Zhang Z, Ye J, Deng Y, Zhou G, Luu HH, Haydon RC, Shi LL, He TC, Wei G: Characterization of constitutive promoters for piggyBac transposon-mediated stable transgene expression in mesenchymal stem cells (MSCs). PLoS One 2014;9:e94397.

43 Song D, Zhang F, Reid RR, Ye J, Wei Q Liao J, Zou Y, Fan J, Ma C, Hu X, Qu X, Chen L, Li L, Yu Y, Yu X, Zhang Z, Zhao C, Zeng Z, Zhang R, Yan S, Wu T, Wu X, Shu Y, Lei J, Li Y, Zhang W, Wang J, Lee MJ, Wolf JM, Huang D, He TC: BMP9 induces osteogenesis and adipogenesis in the immortalized human cranial suture progenitors from the patent sutures of craniosynostosis patients. J Cell Mol Med 2017;21:2782-2795.

44 Zhang F, Li Y, Zhang H, Huang E, Gao L, Luo W, Wei Q, Fan J, Song D, Liao J, Zou Y, Liu F, Liu J, Huang J, Guo D, Ma C, Hu X, Li L, Qu X, Chen L, Yu X, Zhang Z, Wu T, Luu HH, Haydon RC, Song J, He TC, Ji P: Anthelmintic mebendazole enhances cisplatin's effect on suppressing cell proliferation and promotes differentiation of head and neck squamous cell carcinoma (HNSCC). Oncotarget 2017;8:12968-12982.

45 Li Y, Wagner ER, Yan Z, Wang Z, Luther G, Jiang W, Ye J, Wei Q, Wang J, Zhao L, Lu S, Wang X, Mohammed MK, Tang S, Liu H, Fan J, Zhang F, Zou Y, Song D, Liao J, Haydon RC, Luu HH, He TC: The Calcium-Binding Protein S100A6 Accelerates Human Osteosarcoma Growth by Promoting Cell Proliferation and Inhibiting Osteogenic Differentiation. Cell Physiol Biochem 2015;37:2375-2392.

46 Chen X, Liu X, Lang H, Zhang S, Luo Y, Zhang J: S100 calcium-binding protein A6 promotes epithelialmesenchymal transition through beta-catenin in pancreatic cancer cell line. PLoS One 2015;10:e0121319. 


\section{Cellular Physiology Cell Physiol Biochem 2018;47:957-971 \begin{tabular}{cl|l} 
DOI: 10.1159/000490140 & O 2018 The Author(s). Published by S. Karger AG, Basel \\
www.karger.com/cpb
\end{tabular}}

Yu et al.: Repurposing Niclosamide as Anti-RCC Agent

47 He BC, Gao JL, Zhang BQ Luo Q, Shi Q, Kim SH, Huang E, Gao Y, Yang K, Wagner ER, Wang L, Tang N, Luo J, Liu X, Li M, Bi Y, Shen J, Luther G, Hu N, Zhou Q Luu HH, Haydon RC, Zhao Y, He TC: Tetrandrine inhibits Wnt/beta-catenin signaling and suppresses tumor growth of human colorectal cancer. Mol Pharmacol 2011;79:211-219.

-48 Huang J, Bi Y, Zhu GH, He Y, Su Y, He BC, Wang Y, Kang Q Chen L, Zuo GW, Luo Q Shi Q, Zhang BQ Huang A, Zhou L, Feng T, Luu HH, Haydon RC, He TC, Tang N: Retinoic acid signalling induces the differentiation of mouse fetal liver-derived hepatic progenitor cells. Liver Int 2009;29:1569-1581.

49 Untergasser A, Cutcutache I, Koressaar T, Ye J, Faircloth BC, Remm M, Rozen SG: Primer3--new capabilities and interfaces. Nucleic Acids Res 2012;40:e115.

50 Zhang Q, Wang J, Deng F, Yan Z, Xia Y, Wang Z, Ye J, Deng Y, Zhang Z, Qiao M, Li R, Denduluri SK, Wei Q, Zhao L, Lu S, Wang X, Tang S, Liu H, Luu HH, Haydon RC, He TC, Jiang L: TqPCR: A Touchdown qPCR Assay with Significantly Improved Detection Sensitivity and Amplification Efficiency of SYBR Green qPCR. PLoS One 2015;10:e0132666.

51 Chen X, Cui J, Yan Z, Zhang H, Chen X, Wang N, Shah P, Deng F, Zhao C, Geng N, Li M, Denduluri SK, Haydon RC, Luu HH, Reid RR, He TC: Sustained high level transgene expression in mammalian cells mediated by the optimized piggyBac transposon system. Genes Dis 2015;2:96-105.

52 Wang N, Zhang W, Cui J, Zhang H, Chen X, Li R, Wu N, Chen X, Wen S, Zhang J, Yin L, Deng F, Liao Z, Zhang Z, Zhang Q Yan Z, Liu W, Ye J, Deng Y, Wang Z, Qiao M, Luu HH, Haydon RC, Shi LL, Liang H, He TC: The piggyBac transposon-mediated expression of SV40 T antigen efficiently immortalizes mouse embryonic fibroblasts (MEFs). PLoS One 2014;9:e97316.

53 Luo X, Chen J, Song WX, Tang N, Luo J, Deng ZL, Sharff KA, He G, Bi Y, He BC, Bennett E, Huang J, Kang Q, Jiang W, Su Y, Zhu GH, Yin H, He Y, Wang Y, Souris JS, Chen L, Zuo GW, Montag AG, Reid RR, Haydon RC, Luu $\mathrm{HH}, \mathrm{He}$ TC: Osteogenic BMPs promote tumor growth of human osteosarcomas that harbor differentiation defects. Lab Invest 2008;88:1264-1277.

54 Su Y, Wagner ER, Luo Q Huang J, Chen L, He BC, Zuo GW, Shi Q, Zhang BQ Zhu G, Bi Y, Luo J, Luo X, Kim SH, Shen J, Rastegar F, Huang E, Gao Y, Gao JL, Yang K, Wietholt C, Li M, Qin J, Haydon RC, He TC, Luu $\mathrm{HH}$ : Insulin-like growth factor binding protein 5 suppresses tumor growth and metastasis of human osteosarcoma. Oncogene 2011;30:3907-3917.

55 Li R, Zhang W, Cui J, Shui W, Yin L, Wang Y, Zhang H, Wang N, Wu N, Nan G, Chen X, Wen S, Deng F, Zhou G, Liao Z, Zhang J, Zhang Q, Yan Z, Liu W, Zhang Z, Ye J, Deng Y, Luu HH, Haydon RC, He TC, Deng ZL: Targeting BMP9-promoted human osteosarcoma growth by inactivation of notch signaling. Curr Cancer Drug Targets 2014;14:274-285.

56 Luu HH, Kang Q Park JK, Si W, Luo Q, Jiang W, Yin H, Montag AG, Simon MA, Peabody TD, Haydon RC, Rinker-Schaeffer CW, He TC: An orthotopic model of human osteosarcoma growth and spontaneous pulmonary metastasis. Clin Exp Metastasis 2005;22:319-329.

57 Chen L, Jiang W, Huang J, He BC, Zuo GW, Zhang W, Luo Q, Shi Q, Zhang BQ Wagner ER, Luo J, Tang M, Wietholt C, Luo X, Bi Y, Su Y, Liu B, Kim SH, He CJ, Hu Y, Shen J, Rastegar F, Huang E, Gao Y, Gao JL, Zhou JZ, Reid RR, Luu HH, Haydon RC, He TC, Deng ZL: Insulin-like growth factor 2 (IGF-2) potentiates BMP-9induced osteogenic differentiation and bone formation. J Bone Miner Res 2010;25:2447-2459.

-58 Yan Z, Yin L, Wang Z, Ye J, Zhang Z, Li R, Denduluri SK, Wang J, Wei Q, Zhao L, Lu S, Wang X, Tang S, Shi LL, Lee MJ, He TC, Deng ZL: A Novel Organ Culture Model of Mouse Intervertebral Disc Tissues. Cells Tissues Organs 2016;201:38-50.

59 Haydon RC, Deyrup A, Ishikawa A, Heck R, Jiang W, Zhou L, Feng T, King D, Cheng H, Breyer B, Peabody T, Simon MA, Montag AG, He TC: Cytoplasmic and/or nuclear accumulation of the beta-catenin protein is a frequent event in human osteosarcoma. Int J Cancer 2002;102:338-342.

60 Liu X, Qin J, Luo Q Bi Y, Zhu G, Jiang W, Kim SH, Li M, Su Y, Nan G, Cui J, Zhang W, Li R, Chen X, Kong Y, Zhang J, Wang J, Rogers MR, Zhang H, Shui W, Zhao C, Wang N, Liang X, Wu N, He Y, Luu HH, Haydon RC, Shi LL, Li T, He TC, Li M: Cross-talk between EGF and BMP9 signalling pathways regulates the osteogenic differentiation of mesenchymal stem cells. J Cell Mol Med 2013;17:1160-1172.

61 Luu HH, Zhou L, Haydon RC, Deyrup AT, Montag AG, Huo D, Heck R, Heizmann CW, Peabody TD, Simon MA, He TC: Increased expression of S100A6 is associated with decreased metastasis and inhibition of cell migration and anchorage independent growth in human osteosarcoma. Cancer Lett 2005;229:135-148. 


\section{Cellular Physiology Cell Physiol Biochem 2018;47:957-971 \begin{tabular}{l|l} 
DOI: 10.1159/000490140 & O 2018 The Author(s). Published by S. Karger AG, Basel \\
www.karger.com/cpb
\end{tabular}}

Yu et al.: Repurposing Niclosamide as Anti-RCC Agent

62 Tumova L, Pombinho AR, Vojtechova M, Stancikova J, Gradl D, Krausova M, Sloncova E, Horazna M, Kriz V, Machonova O, Jindrich J, Zdrahal Z, Bartunek P, Korinek V: Monensin inhibits canonical Wnt signaling in human colorectal cancer cells and suppresses tumor growth in multiple intestinal neoplasia mice. Mol Cancer Ther 2014;13:812-822.

63 Arend RC, Londono-Joshi AI, Straughn JM, Jr., Buchsbaum DJ: The Wnt/beta-catenin pathway in ovarian cancer: a review. Gynecol Oncol 2013;131:772-779.

64 Yang K, Wang X, Zhang H, Wang Z, Nan G, Li Y, Zhang F, Mohammed MK, Haydon RC, Luu HH, Bi Y, He TC: The evolving roles of canonical WNT signaling in stem cells and tumorigenesis: implications in targeted cancer therapies. Lab Invest 2016;96:116-136.

65 Mohammed MK, Shao C, Wang J, Wei Q, Wang X, Collier Z, Tang S, Liu H, Zhang F, Huang J, Guo D, Lu M, Liu F, Liu J, Ma C, Shi LL, Athiviraham A, He TC, Lee MJ: Wnt/beta-catenin signaling plays an ever-expanding role in stem cell self-renewal, tumorigenesis and cancer chemoresistance. Genes Dis 2016;3:11-40.

66 Sun T, Liu H, Ming L: Multiple Roles of Autophagy in the Sorafenib Resistance of Hepatocellular Carcinoma. Cell Physiol Biochem 2017;44:716-727.

67 Pirrotta MT, Bernardeschi P, Fiorentini G: Targeted-therapy in advanced renal cell carcinoma. Curr Med Chem 2011;18:1651-1657. 